\title{
A Comparison Study of Some Flood Estimation Methods in terms of Design of Water Structures
}

\author{
Necati Gulbahar** \\ *Department of Civil Engineering, Faculty of Engineering and Architecture, Istanbul Gelisim University, Istanbul, Turkey. \\ (ngulbahar@gelisim.edu.tr) \\ ${ }^{\star}$ Corresponding Author; Necati Gulbahar, Department of Civil Engineering, Faculty of Engineering and Architecture, Istanbul \\ Gelisim University, Istanbul, Turkey, Tel: +90 212422 7020, Fax: +90 212422 7401, ngulbahar@gelisim.edu.tr
}

Received: 17.02.2016 Accepted: 04.03.2016

\begin{abstract}
Flood is a natural disaster that caused the death of many people, environmental destruction and economical loses. Therefore, it is must be taken under control and prevent damage to the people and environment. Particularly, cities and villages have been often faced with floods that result from engineering and planning errors in Turkey. As a conventional approach, some certain calculations methods have been developed in order to estimate flood discharge, velocity, depth and recurrence in this regard. Some of them are widely used for the flood estimation such as; unit hydrograph, stochastic and statistical, Rational, MacMath, Kirpich, Mockus, SCS, Snyder and Degree-Day methods. Because, every method has some significant limiting conditions, each one gives different results for same place. According to recent researches, selection of the proper method is very important to reach more accurate results, but the best one is measuring. Therefore, a suitable method to meteorological, hydrologic, topographic conditions of a basin should be selected for the successful application. In this paper, some common conventional methods were discussed and evaluated for the aim of performing better results.
\end{abstract}

Keywords: Flood, comparison, structures, rational method

\section{Introduction}

Throughout the history, humans have wished to settle in the coastal area of river, lakes and sea. Of course, there are many reasons for this attitude. One of the most important reason is that human needs of water for the life and must use it for various purposes in agriculture, industry and other activities. On the other hand, those attractive places are very risky region in terms of natural disasters such as earthquake, flood and, landside. Flood can be defined as it spreads over the land and damages surroundings as water flows at high speed and big discharge. In facts, floods are natural disasters which cause loss of lives after earthquakes in the world.

Generally, in order to design the hydraulic structures, it is necessary to obtain the data based on meteorology and hydrology at least 30 years. However, the gauge stations may not be sufficient in terms of quantity and quality in any country.

Looking at the history, the archaeological studies show that floods have damaged to human such as Tigris and Euphrates in Mesopotamia; The Nile in Egypt; Ganges and Indus in India and Yellow River in China.

The first studies in the modern sense began in Netherland in 1544. Recently, European Union (EU) Directive numbered 2000/60/EC with the name of Water Frame Work was emphasized an Integrated Watershed Management and European Parliament and EU Commission with the numbered 2007/60/EC Directive also stated the floods as unavoidable hazard that caused the people's dead, damaged the environment, cultural heritage, economic development and infrastructures. However, it is stated in the same directive that it is also possible to reduce these losses. Therefore, it has been made compulsory to do preliminary flood risk assessment, flood hazard maps, flood risk map and flood risk management plans for a member states up to the certain date.

There are some challenges in this regard that need to be fighting in Turkey. According to research of General Management of Natural Disaster, the most common natural disasters are landslide, earthquake and flood have been occurred frequently in the country. From Fig. 1 it can be seen as landslide (45\%), earthquake (18\%) and flood (14\%) frequently occurred in the country. So, this subject is more important for Turkey than Europe.

Another challenge is that, works carried out by institutions are scattered with no cooperation because there is not a general technical regulation covering general rules for combating flood [6]. 


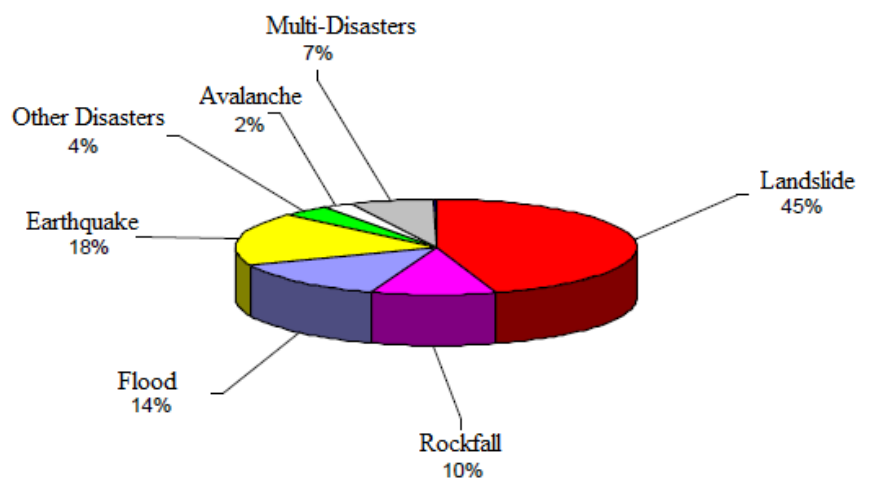

Fig. 1. Distribution of type of disaster [8]

In parallel to works done in Europe, it has been carried out some significant studies in this field under planning and control of General Directorate of State Hydraulics Works (DSI) which is only public authority in flood in Turkey. Besides, it was also stated some necessary measures to be taken at the Directives of Prime Ministry with the numbered 2006/27 Creek Beds and Floods and 2010/5 numbered Rivers and Creek Beds Improvement. However, some important developments have been achieved in this regard recently, such as; creek development, channel capacity enlargement, urban renewal.

Generally, in order to design the structures for flood in any area, the level, magnitude and variation of peak discharge, recurrence of precipitation must be determined. The most common used equations for the estimation of these parameters are known as unit hydrograph, stochastic and statistical method, Rational, Mac Math, Mockus, SCS, Kirpich, Snyder and Degree-Day method.

Since each method has different characteristics and coefficients, different results will be obtained naturally. In this study, these subjects will be discussed and evaluated based on conventional method.

\section{Material and Method}

Mainly, two approaches have been used for determining flood discharge; one is conventional method the other is simulation by computer. If the necessary hydrological and meteorological data from a gauge stations in a basin can be obtain, then calculation can be made safely. If not available, then synthetic methods can be used for estimation of flood discharge utilizing the values of similar basin.

Another way is that the necessary parameters are determined and scanned by computer which is called simulation method. There are many simulations methods for the subject such as STORM, SWMM, USGS, HEC-RAS and MIKE serious. However, conventional method will be evaluated in this paper.

\section{Discussion and Evaluation}

Generally, equations of flood discharge were briefly explained and clarified their restrictive conditions at the following.

\subsection{Stochastic and statistical method}

These methods are based on the extreme distributions of precipitation which are Gumbel, Pearson, log-normal, Gamma that are proposed to use by DSI in Turkey. However, package programs have been used for using these methods. Probable maximum rainfall depth could be found by the following formula;

$\mathrm{X}=\mu \mathrm{X}+\mathrm{K} \sigma \mathrm{x}$

Where;

$\mathrm{X}$ : maximum precipitation with $\mathrm{T}$ year frequency $(\mathrm{mm})$

$\mu \mathrm{x}:$ arithmetic average of annual rainfall series $(\mathrm{mm})$

$\sigma \mathrm{x}:$ standard deviation of rainfall series $(\mathrm{mm})$

$\mathrm{K}$ : frequency coefficient depending on rainfall series

\subsubsection{Unit hydrograph method}

The unit hydrograph of a basin is defined as the hydrograph of surface runoff from $1 \mathrm{~cm}$ of excess rainfall generated uniformly over the basin at uniform rate during the specific period of time [2]. Accordingly, unit hydrograph of a watershed can be found from falling constant intensity and distributed evenly hydrograph basin Fig. 2. This is a method that results closest to actual values than the other methods. Flow depth is found by measuring the area under the hydrograph;

$\mathrm{d}=\mathrm{V} / \mathrm{A}=\mathrm{Q} * \mathrm{t} / \mathrm{A}$

Where;

$\mathrm{d}$ : the depth of flow (m)

$\mathrm{V}$ : volume of water

Q: discharge

A: area

t: time

There are also some restrictive conditions in the unit hydrograph method. Each basin must have the rainfall and flow data. Usually, this is not possible in practice. In addition, from the precipitation of complex compounds, the separation of individual storm is not easy. Tools may be defective or may not work during rainfall. Under these conditions, the improper results may be obtained. Also, if the basin is very large, the distribution of the precipitation is not uniform throughout the basin. In this case, you need to split basin into smaller sub-basin [11].

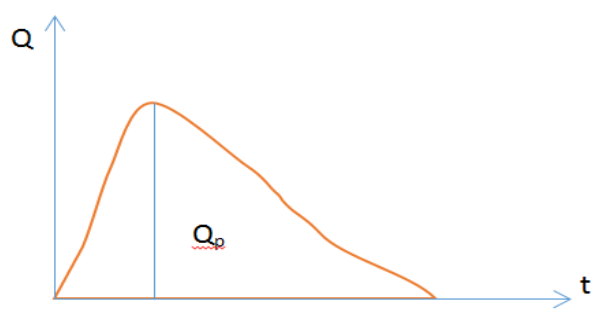

Fig. 2. Unit hydrograph 


\subsection{Rational Method}

It is related rainfall to the corresponding runoff in the basin. It is introduced to scientific community by Kuichling in 1889. This method was developed in USA. It is the simplest and most common used method for flood estimation. The biggest disadvantage of this method is that it cannot be used for large areas. The size of basin should be no more than $25 \mathrm{~km} 2$ for this method. Because, total area of basin is considered as least the precipitation should continue until the duration of conservation time. In that case, the probability of precipitation uniformity will decrease. In the other hand, it takes time to fill the surface transmission channels [11].

The idea behind the rational method in that if a rainfall of certain intensity begins instantaneously and continues indefinitely the rate of runoff will decrease until the time concentration. The entire basin continues to flow at the outlet, then stays constant [11]. The formula below shows that, the rainfall intensity is taken equal to the concentration time and $\mathrm{C}$ coefficient represents topography and plant cover on the land;

$\mathrm{Q}_{\mathrm{p}}=0.278 * \mathrm{C} * \mathrm{I} * \mathrm{~A}$

$\mathrm{T}_{\mathrm{c}}=0.0195 \mathrm{~K}^{0.77}$

$\mathrm{K}=\mathrm{L}^{3 / 2} / \mathrm{H}^{1 / 2}$

Where;

$Q_{p}:$ the peak flow rate $\left(\mathrm{m}^{3} / \mathrm{s}\right)$

$\mathrm{C}$ : runoff coefficient (dimensionless)

$\mathrm{I}:$ the average rainfall intensity $(\mathrm{mm} / \mathrm{h})$

A : the drainage area $\left(\mathrm{km}^{2}\right)$

$\mathrm{L}$ : length of drainage channel $(\mathrm{km})$

$\mathrm{H}$ : the difference between beginning and end of channel

\subsubsection{Kirpich's Equation}

The equation developed in Tennessee State in USA by Kirpich in 1940 for rural areas where slope in high then 10\% and is suitable land cover in timber in more than $59 \%$ of area. The formula is preferred because it is simple and easy application [10]. The formulas are given at the following;

$\mathrm{t}_{\mathrm{f}}=\mathrm{t}_{\mathrm{e}} / 2+\mathrm{t}_{\mathrm{p}}$

$\mathrm{t}_{\mathrm{e}}=\mathrm{t}_{\mathrm{r}}=\mathrm{t}_{\mathrm{p}} / 5.5$

$\mathrm{Q}_{\mathrm{p}}=\mathrm{k} * \mathrm{~A} * \mathrm{~h}_{\mathrm{a}} / \mathrm{t}_{\mathrm{f}}$

Where;

$\mathrm{Q}_{\mathrm{p}}$ : peak discharge $\left(\mathrm{m}^{3} / \mathrm{s}\right)$

$\mathrm{t}_{\mathrm{f}}:$ rainfall duration $(\mathrm{h})$

$\mathrm{t}_{\mathrm{e}}$ : effective duration of precipitation

$t_{\mathrm{p}}$ : the time difference between the peak point of hydrograph and the basin center of gravity

$\mathrm{h}_{\mathrm{a}}$ : annual rainfall depth for 100 years $(\mathrm{cm})$ $\mathrm{k}$ : coefficient $(0.208)$

A: area $\mathrm{km}^{2}$

\subsubsection{SCS Equation}

In 1957, it is developed for smaller basin than $30 \mathrm{~km} 2$ by the U.S. Soil Conservation Service (SCS) in the USA. It has dimensionless triangle hydrograph which is derived from a number of basins in different geographical regions. The advantages and the disadvantages are could be summarized as follows [11];

Advantages:

- It is widely used in basins smaller than $30 \mathrm{~km}^{2}$

- The equation is simple

- Provides the results close to actual values

- Uses the daily precipitation values

Disadvantages;

- Drainage area should have a curve number

- Drainage area must be homogenous

The equations are given below:

$\mathrm{t}_{\mathrm{c}}=0.066\left(\mathrm{~L}^{2}{ }_{\mathrm{h}} / \mathrm{H}\right)^{0.385}$

$\mathrm{D}=0.133 * \mathrm{t}_{\mathrm{c}}$

$\mathrm{L}=0.6 * \mathrm{t}_{\mathrm{c}}$

$\mathrm{t}_{\mathrm{p}}=(\mathrm{D} / 2)+\mathrm{L}$

$\mathrm{S}=(1.000 / \mathrm{CN})-10$

$\mathrm{h}_{\mathrm{e}}=\left(\mathrm{h}_{\mathrm{a}}-1\right) 2 /\left(\mathrm{h}_{\mathrm{a}}-1+\mathrm{S}\right)$

$\mathrm{Q}_{\mathrm{p}}=\left(0.2083 * \mathrm{~A} / \mathrm{t}_{\mathrm{p}}\right) * \mathrm{~h}_{\mathrm{e}}$

Where;

$\mathrm{Q}_{\mathrm{p}}$ : the peak flow rate $\left(\mathrm{m}^{3} / \mathrm{s}\right)$

$t_{p}$ : time of peak $(h)$

$\mathrm{t}_{\mathrm{f}}$ : time of fall (h)

$t_{c}$ : time of concentration(h)

$\mathrm{h}_{\mathrm{e}}$ : maximum flow height $(\mathrm{mm})$

A : drainage area $\left(\mathrm{km}^{2}\right)$

\subsubsection{Mac Math Equation}

This method can be used at every type of smooth and undulating land. It gives good results in the calculation of the capacity of surface drainage canals. It does not give good results for the land with steep slopes. The formula is as follows [5] and [11];

$\mathrm{Q}_{\mathrm{p}}=0.0023 * \mathrm{C} * \mathrm{I} * \mathrm{~S}^{1 / 5} * \mathrm{~A}^{4 / 5}$

$\mathrm{t}_{\mathrm{c}}=0.0195\left(\mathrm{~L}^{3} / \mathrm{H}\right)^{0.385}$

Where;

$\mathrm{Q}_{\mathrm{p}}$ : the peak flow rate $\left(\mathrm{m}^{3} / \mathrm{s}\right)$

$\mathrm{C}$ : this is a coefficient depending on topography, plant cover and soil 
I : Average rainfall intensity for certain recurrence duration and time of concentration $(\mathrm{mm} / \mathrm{h})$

$\mathrm{S}:$ slope of the main channel (1000)

A : basin area (ha)

$\mathrm{t}_{\mathrm{c}}:$ time of concentration (min)

$\mathrm{L}$ : length of basin or channel $(\mathrm{km})$

$\mathrm{H}$ : the difference between beginning and end of channel (m)

\subsubsection{Mockus Method}

The method which was developed by Victor Mockus is easy to practice and to draw triangular hydrograph. In general triangular hydrographs are sensitive as other normal hydrographs. But, there are some restrictive conditions such as time of concentration up to 30 minutes in the basin, when the recession curve is necessary and selection unit time of rainfall[11].The formulas are as follows;

$\mathrm{t}_{\mathrm{c}}=0.00032\left(\mathrm{~L}_{\mathrm{h}}^{0,77} / \mathrm{S}^{0.385}\right)$

$\mathrm{D}=2 * \mathrm{t}_{\mathrm{c}}{ }^{1 / 2}$

$\Delta \mathrm{D}=\mathrm{t}_{\mathrm{c}} / \mathrm{S}$

$\mathrm{t}_{\mathrm{p}}=0.5 * \Delta \mathrm{D}+0.6 * \mathrm{t}_{\mathrm{c}}$

$\mathrm{q}_{\mathrm{p}}=\mathrm{K}^{*} \mathrm{~A} / \mathrm{t}_{\mathrm{p}}$

$\mathrm{Q}_{\mathrm{p}}=\mathrm{q}_{\mathrm{p}} * \mathrm{~h}_{\mathrm{a}}$

Where;

$\mathrm{t}_{\mathrm{c}}=$ time of concentration $(\mathrm{h})$

$\mathrm{L}_{\mathrm{h}}=$ the length of drainage area $(\mathrm{m})$

$\mathrm{S}=$ average slope of drainage area $(\%)$

$\mathrm{D}=$ time of duration of precipitation (h)

$\Delta \mathrm{D}=$ time of heavy rainfall $(\mathrm{h})$

$t_{p}=$ the time of duration for peak discharge $(h)$

$\mathrm{h}_{\mathrm{a}}=$ annual rainfall depth of 100 years $(\mathrm{cm})$

$\mathrm{k}=$ coefficient of basin (0.21-1.60)

$\mathrm{q}_{\mathrm{p}}=$ discharge generated by $1 \mathrm{~mm}$ rainfall

$\mathrm{Q}_{\mathrm{p}}=$ discharge generated by 100 years rainfall (m3/s)

\subsubsection{Snyder Method}

This is one of the synthetic methods to obtain unit hydrograph which was suggested by Snyder in USA in 1938. The main idea of this method is that the basin characteristics which are area, shape, topography, channel slope, stream density are affected the shape of unit hydrograph. After having studied on many hydrographs of the basins in North America, it was defined as a standard unit hydrograph. Snyder method cannot widely used in Turkey, because, basin coefficients are not determined in all basins in Turkey $[9,11]$.

The formulas are given as follows;

$\mathrm{t}_{\mathrm{r}}=\mathrm{t}_{\mathrm{p}} / 5,5$ $\mathrm{t}_{\mathrm{p}}=0,75 \cdot \mathrm{C}_{\mathrm{t}}\left(\mathrm{L} \cdot \mathrm{L}_{\mathrm{c}}\right)^{0,3}$

$\mathrm{q}_{\mathrm{p}}=2,75 . \mathrm{C}_{\mathrm{p}} / \mathrm{t}_{\mathrm{p}}$ peak discharge

$\mathrm{t}_{\mathrm{p}}=\mathrm{t}_{\mathrm{pR}}+0.25\left(\mathrm{t}_{\mathrm{r}}-\mathrm{t}_{\mathrm{R}}\right)$

Where;

$\mathrm{t}_{\mathrm{r}}$ : effective precipitation

$\mathrm{t}_{\mathrm{p}}$ : basin delay $(\mathrm{h})$

$\mathrm{q}_{\mathrm{p}}$ : peak discharge per unit area $\left(\mathrm{m}^{3} / \mathrm{sec} / \mathrm{km}^{2}\right)$

$\mathrm{C}_{\mathrm{p}}$ : basin coefficient

$\mathrm{C}_{\mathrm{t}}$ : basin coefficient

There are also some limitations with this formula. If $t_{P R}=5,5 . t_{R}$ then, $t_{R}=t_{r}$ and $q_{P R}=q_{P}$ can be taken, and $C_{t}$ and $\mathrm{C}_{\mathrm{p}}$ can be obtained above equation. $\mathrm{C}_{t}$ and $\mathrm{C}_{\mathrm{p}}$ is a function of basin characteristics and slope. If $t_{P R}$ is different from 5,5. $\mathrm{t}_{\mathrm{r}}$; then basin lag calculated with the following formula;

$t_{p}=t_{P R}+0.25\left(t_{r}-t_{R}\right)$

\subsubsection{Degree - Day method}

Usually, floods from snow melt may occur in any day in the springs. There are some methods for calculation the snow melts. In order to calculate flood from snow melt Degree Day method or some empirical equations could be applied. The degree day method is simple and easy to apply. The basis of the method is that water depth coming from snow melt in a day is proportional with the temperature [2]. The formula is as follows;

$\mathrm{M}=\mathrm{k} * \mathrm{~T}$

Where;

$\mathrm{M}=$ water level after snowmelt for a day ( $\mathrm{mm})$

$\mathrm{K}=$ coefficient of degree day (2-4)

$\mathrm{T}=$ temperature $\left(\mathrm{C}^{\mathrm{O}}\right)$

As seen above each method has different characteristics. In this regard, recent studies are examined; significant differences can be seen from each other for the same area. Certainly, this is an expected result. In a study conducted for Istanbul, the obtained results are different each other. Table 1 and Table 2 show that Snyder gives maximum values while SCS gives the minimum ones. As a function of topography, maximum value was obtained in Sazlidere. But, all methods gave close results for only Sariyer.

Table 1.The data of some selected streams [10]

\begin{tabular}{|c|c|c|c|}
\hline $\begin{array}{c}\text { Stream } \\
\text { Name }\end{array}$ & Slope & $\begin{array}{c}\text { Area } \\
\left(\mathbf{k m}^{2}\right)\end{array}$ & $\begin{array}{c}\text { Rainfall Depth } \\
(\mathbf{m m})\end{array}$ \\
\hline Alibeykoy & 0,0025 & 34,465 & 105,00 \\
\hline Ayamama & 0,0049 & 47,903 & 23,03 \\
\hline Sariyer & 0,0095 & 7,266 & 24,00 \\
\hline Nakkas & 0,00005 & 44,906 & 44,29 \\
\hline Kurbagalidere & 0,0049 & 47,304 & 24,00 \\
\hline Sazlidere & 0,00031 & 52,775 & 347,14 \\
\hline Tugay & 0,0098 & 24,255 & 62,22 \\
\hline Kemikli & 0,0049 & 63,020 & 28,00 \\
\hline
\end{tabular}


Table 2.Comparison of flood discharge for each method [10]

\begin{tabular}{|c|c|c|c|c|}
\hline \multirow{2}{*}{$\begin{array}{c}\text { Stream } \\
\text { Name }\end{array}$} & \multicolumn{4}{|c|}{ Flood Discharge for 100 years $\left.\mathbf{~ m} \mathbf{3}^{\mathbf{3}} \mathbf{s}\right)$} \\
\cline { 2 - 5 } & Snyder & Kirpich & Mockus & S.C.S \\
\hline Alibeykoy & 399,00 & 262,54 & 218,16 & 169,36 \\
\hline Ayamama & 122,09 & 81,66 & 51,14 & 44,13 \\
\hline Sariyer & 33,60 & 29,43 & 35,95 & 38,92 \\
\hline Nakkas & 168,30 & 117,35 & 37,75 & 6,58 \\
\hline Kurbagalidere & 117,60 & 82,68 & 41,41 & 36,89 \\
\hline Sazlidere & 2291,00 & 1589,00 & 124,27 & 383,83 \\
\hline Tugay & 180,53 & 125,72 & 109,08 & 108,26 \\
\hline Kemikli & 196,00 & 135,53 & 46,20 & 39,43 \\
\hline
\end{tabular}

According to another study carried out for the same place in Istanbul; Snyder, Mockus, Iszkowski and Lauterburg methods were tested and the results were seen in Fig. 3. The results are completely different from each other. In Fig. 4 Calculated results are compared with reference to measurement results. The results are close to each other for Nakkas and Kurbagalidere, but they are far from each other for Kagithane.

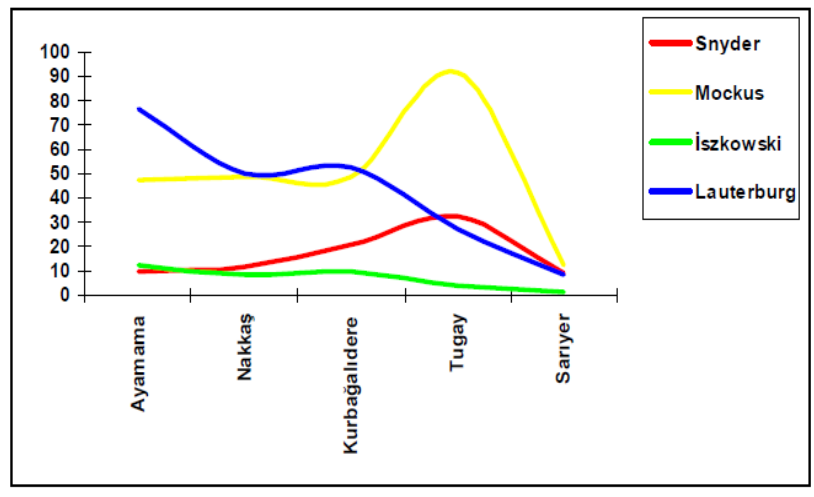

Fig. 3. Comparison of Discharge Values [3]

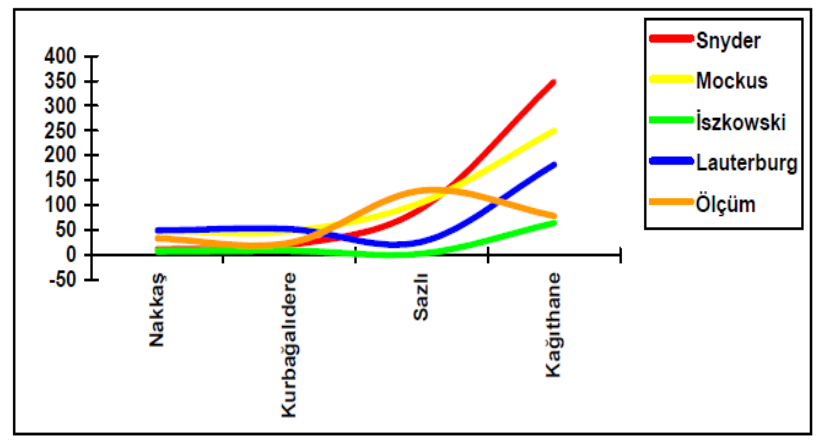

Fig. 4.Comparison of methods used and measurement [3]

\section{Conclusion}

Generally, differences observed from equations are resulted from both basin and equations. Considering basin, each basin has different meteorological, topographical, hydrologic, hydraulic conditions. Each basin may have not gauge station. On the other hand, assumptions of the equations and coefficient are different each other. All methods are based on a uniform distribution of precipitation in a given area which is not possible in nature.
Hydrological events have variable and uncertainty characteristics. Therefore, they contain both deterministic and stochastic components. In these methods, past data have evaluated and estimated future values. Certainly, they also contain some risks.

Because of based on measuring data, the unit hydrograph method results are closest to actual values. Coefficients are not used and assumptions are close to actual situations. If there is no sufficient data, the synthetic hydrograph methods should be used. In that case, similarity should be provided precisely.

One of the common used synthetic methods is Snyder which results more than the actual values. Probably, this might be come from the coefficients which represents of basin characteristics. Snyder method is to make calculations taking into account the geometry of the basin. However, the method is not suitable for smaller basin than $30 \mathrm{~km}^{2}$.

However, SCS is one of the recently developed methods having simple triangular shape to determine to runoff from rainfall for smaller areas than $30 \mathrm{~km}^{2}$ in USA. In the test, SCS gave minimum values for same area. Thus, type of land use and curve number must be chosen very carefully.

Rational and Mac Math method are used widely in the country and abroad. While Mac Math gives good results for calculation of channel capacity at all sizes of area but, it does not give good results at hilly and uneven lands. Rational method is more suitable for small areas in cities which is smaller from $25 \mathrm{~km}^{2}$. The rainfall intensity related to soil permeability and the coefficient of representing the plant cover in the field should be determine carefully in this $\mathrm{m}$

Mockus method gives results closer to actual values according to Snyder Method. Probably, this is because the calculation is made taking into account the slope of the creek and flow depth.

Because Iszkowski ve Lauterburg methods gave disproportionate and different results than the others, the tests should be repeated in any other basins.

Kirpich method has the triangle hydrograph and the formula is simple and convenient for the application. It is preferred where the slope is higher than $10 \%$ and the wooded areas are more than $60 \%$.It could be used safely in case of the absence of withdrawal curve is not significant.

Although, Degree-day method is simple and practicable in calculations of discharge from snow, but wind speed, vegetation, rainfall, soil structure are taken into account with this formula.

As a result, most of the empirical and deterministic methods used in flood flow calculation are based on the characteristics of the river basins where they were tested. Therefore, the hydrological, meteorological, topography, plant cover conditions of basin are the most important issues. On the other hand, the assumptions of formulas, characteristics and coefficients are different from each other. As a result, considering restrictive conditions and properties both basin and equations mentioned above, calculations of discharge should be made. 


\section{References}

[1] Bahceci I., Drenaj Mühendisliği, Harran Üniversitesi, Ziraat Fakültesi, Ders Notu, 2010.

[2] Beyazit M., Hidroloji, İTÜ Basımevi, İstanbul, 1995.

[3] Bingöl Y., İstanbul Derelerinin Mevcut Durumu ve Taşkın Debilerinin Hesapları, Yüksek Lisans Tezi, FBE, İTÜ, İstanbul, 2006.

[4] Taşkın Hidrolojisi Tasarım Rehberi, T.C Orman ve Su İşleri Bakanlığı, DSI Genel Müdürlüğü, 1. Barajlar Kongresi, Ankara, 2012.

[5] Güngör Y. and Erözel A, Drenaj ve Arazi Islahı, Ankara Universitesi, Ziraat Fakültesi, Ankara, 1994.

[6] Haltaş İ., Türkiye'de Yürütülen Taşkın Çalışmaları İçin Bir Rehber ve Genel Şartname İhtiyacı, Zirve Üniversitesi, Gaziantep.

[7] Okman C., Hidroloji, Ankara Üniversitesi Ziraat Fakültesi, Ankara, 1994.

[8] Gökçe O., Şenay Ö and Demir A., Afet İşleri Genel Müdürlüğü Envanteri, Ankara, 2008.

[9] Özbek T., Sulama Kurutma, Gazi Üniversitesi, Mühendislik ve Mimarlık Fakültesi, Basın Yayın Yüksek Okulu Matbaası, pp.130-135, Ankara, 1987.

[10] Sönmez O., Öztürk M. and Doğan E., İstanbul Derelerinin Taşkın Debilerinin Tahmini, SAÜ FBE Dergisi, Vol. 16, No. 2, 2012

[11] Usul N., Engineering Hydrology, ODTU Yayıncılık, Ankara, 2008. 